\title{
NARRATIVE IN ADVERTISING: PERSUADING THE NIGERIAN AUDIENCE WITHIN THE SCHEMATA OF STORYLINE
}

\author{
TAOFEEK DALAMU \\ University of Lagos, Akoka, Yaba, Nigeria \\ lifegaters@yahoo.com
}

\section{ABSTRACT}

The study, as an attempt, considered narrative as a good resource of advertising in the Nigerian environment. In other words, advertisers perceive narrative as a strategy that can stimulate consumers to patronize advertised goods and services. Four adverts of FBN $®$, MTN $®$, Orijin ${ }^{\circledR}$ and FIRS ${ }^{\circledR}$ have been chosen to propagate the course appeared on the frameworks. Beside the application of the Labovian schema on narrative, the Halliday's transitivity system plays an analytical role by assigning semiotic slots to the textual devices. The study reveals that advertising copies a similar pattern of narrative in the society. Apart from the texts serving as relays to the images, the construction of the message is in the resolution sequential string. This provides an opportunity for advertisers to present to the public the gains and benefits of taking decision parallel to the messages of the adverts. Advertisers capitalize on the efforts of past leaders, the challenges of the present and the future of the children to sensitize the audience. The study concludes that narrative should be encouraged in advertising not only as a persuasive approach but also as a means of promoting Nigerian social heritage and treasures.

KEYWORDS: Advertising, Circumstances, Narrative, Narratology, Processes and Social Structure

\section{INTRODUCTION}

There are no limitations to resources that can be featured in advertising provided the resources are within the ambit or scope of social strata's ethical values. Advertising quick-witted materials cut across genres and spans of life because every copywriter (use synonymously with advertiser) performs dual purposes. A copywriter is an executive of the product's advocacy as well as the public mobilizer. As one observes adverts (henceforth: ads/ad) everywhere, it seems that there is an agreement among copywriters that the production of adverts should focus social activities of the target audience. This occurs in such a way that hardly can someone divorce advertising from its social connections. Almost every ad has a direct participation in the social processes of the social actors in social systems. For instance, it is in that sense that the author has analyzed elsewhere the MTN ${ }^{\circledR}$ ad - Sharing is good; Guinness ${ }^{\circledR}$ ad - Orijin ${ }^{\circledR}$ Celebrate your orijin; Cocacola ${ }^{\circledR}$ ad - Taste the feeling; Seven-Up ${ }^{\circledR}$ ad - Felabration and Power Oil ${ }^{\circledR}$ ad - World food day. The frameworks are produced and functioned in the workshop of social reproduction as channels of tying advertising processes and products advertised with social values. They are 
adopted to perform an interfacing function between the product and the public in order to mobilize consumers to patronize the advertised product.

If one tends to depict copywriters as product's advocates, then, there is an urgent need to recall the mission of advertising. Every ad intends to persuade the audience to take a crucial decision in favor of the counsel and dictate of the ad-cum-advertiser. This sole aim compels copywriter to mandatorily present the "good news" of the product to the public as a convincing "joker" that can elicit quick consumption. It is from that intellectual stance that the presentation of product is shaped in several forms. The selling ideas can be generated in relation to the contents of the product or the company that produces it. Copywriters fabricate opinions that reflect a particular ingredient of the product in question. They do link up, as well, the product to a celebrated figure in the social system. There are cases (e.g. Orijin ad) where the culture of the people, the source of the people or what the people treasure and fall in love with or hold at high esteem are constructed around the product. Besides, to a large extent, the product is interchanged with ideological reality of the audience. Such a quest for convincing materials put massive pressure on advertising professionals to see narrative as a window of attraction. Narrative has a notational system that can influence the public to dance to tunes played in advertising. The choice of narrative in advertising cannot be separated from the groundwork it serves in human activities (Carter and Nash 1990). It is from that standpoint that one singles out the task of critical examination of narrative deployed in advertising as persuasive strategy that promotes product's patronization. In other words, the paper analyzes advertising texts operating within the cultural undertones of narratology. This serves as an avenue to describe the voice of a dramatis persona in advertising plates.

\section{MAIN SECTION}

\subsection{Literature Review}

\subsubsection{Narrative and Functional Domains}

The process of describing an event seems a long time activity. It has become an inevitable part of human socio-cultural exercises. This makes narrative (we portray narrative as a concept; the reason for eliminating its determinant; it is also used synonymously with anecdote, recit, story, tale and histoire) to be classified as a universal phenomenon. The cultural norm is the divide that places demarcation between the narrative of one social system and the other in a dialectical study. The imperative it has as a collective object is observed by Johnstone when he argues that "The essence of humanness, long characterized as the tendency to make sense of the world through rationality, has come increasingly to be described as the tendency to tell stories, to make sense of the 
world through narrative" (Johnstone 2002: 635). There is a correlation, as Johnstone asserts, between language and narrative. Chomsky has said that language is the essence of humanity (1972) and Johnstone reverberates a similar course by re-echoing that narrative plays a similar role in humanity and the environment. It means that as language cannot be retired from human existence so also is narrative. Recounting a particular event from a persona to a receiver (or receivers) is a means of sharing experience with the individual. The episode shared may be for a purpose of understanding a piece of information or a way of letting people learn one or two things from it. Carter and Nash (1990: 77) submit that "Narratives shape our lives as well as the understanding of our lives." The concept of narrative constructs a particular way of life for us by what is called Analepsis (Barry 2009: 226). It refers to flashing back on a previous event which tends to produce great lessons. Such lessons can safeguard humanity against falling into the pit of life challenges.

Narratives can be antiquated, of the recent past or of personal experience. Each of them has a common place that is dotted with lines of fictional apparatuses. These seem the reason that narrative is shaped in varying heights of directness and indirectness (Carter and Nash 1990). Narrative of the ancient appears fictional because the narrator receives it as a secondary material. One advantage that the personal experience narrative (PEN) may have over others is that its materiality is fundamentally primary. It is first-class information that is easy to process linguistically semantically. Narrative is objective and most times factual. Sometimes, it might not reflect reality. Notwithstanding of its inherent objectivity, a narrator can be subjective when such a persona filters the substance of the anecdote. The individual presents to the listener, at liberty, the replay of what a subject wants the individual to hear and understand (Jaworski and Coupland 2006: 26-27). However, events of medical history seem non-fiction for they relate to health matters. The patient most times tends to recite to the doctor the feelings in the body without any addition or subtraction. The patient may decide to tell the doctor all events in altruism so that appropriate medication can be prescribed for the affected person. Fleischman takes up the altruistic notion of narrative in medicine when she explains that;

\footnotetext{
Narratologists who have studied nonfictional narrative are keenly aware that what storytellers provide is not a verbal icon of pre-existing structure of real-world experience. Rather, they cull from, and configure, the experiential database from which the story is constructed, notably in ways that support the point they wish to make in telling the story (Fleischman 2002: 480).
}

The aim of any patient in telling the doctor a tale is different from the objectives of other forms of narrative which motivation is outside medication. The individual explains to the doctor the health problems in order to get well 
and neither to impress him nor catch the attention of the medical personnel. So, there is no need to relate such a story as an element of rhetorical puns.

Scholars including Johnstone have argued that narrative is "any talk representing a sequence of past events for talk specifically meant to get and keep someone interested in listening to a recounting of events" (Johnstone 2002: 639). In addition to narrative forms a number of functions are exemplified. One of the narrative's performative acts is human beings' natural obligation to discuss their (or others) past events. These attributes of a society inflate Linde to state that "In order to exist in the social world with a comfortable sense of being... socially proper... an individual needs to have a coherent, acceptable, and constantly revised life story" (Linde 1993: 3). Describing the incident of the past, in Linde's perspective, is a social enterprise that provides the dramatis persona a sense of belonging. While Silberstein (1988: 126) describes narrative as a facility for creating and sustaining gender relationships and issues, Porter (1988: 545) sees it as a prominent verbal tool of comparison. It assists to reconcile the past with the present systematic activities.

Of course, there are other researchers who perceive narrative officiating as a business of building interrelationships among the people (Coates 1996), by making social groups to cohere (Patrick and Taylor-Jackson 1996) and indicating patriarchal responsibility of fathers (Ochs and Taylor 1992). It is also mentioned that the subject assists in the construction of different social systems from the basis of family lineage to the origin of the society that the individuals belong. From a judicial angle, narrative serves as a style of self-expression and an interpretation of violation of expectations. It also supports in demonstrating personal justification of the action of the persona. Therefore, if narrative serves immensely for negotiating social ideology and social relations; it then becomes a useful instrument for peaceful co-existence and emancipation for socially illegitimate burdens (Johnstone 2002: 635-643). Narrative seems a ritual that fosters great collaborations among human beings in the global social strata.

\subsubsection{Narratology and Structural Connections}

The notion of narratology is an academic framework that is coined similar in nature to the way, for example, sociology is constructed. As sociology, from a layman's perspective, is the study of facilities that operate in a social system; it is in a parallel platform that one can describe the construct of narratology. According to Barry (2009: 214), the descriptions of narratology go thus: "the study of narrative structure" which is perceived as "an attempt to study the nature of story as a concept and as a cultural practice." The author refers to the term, structure, as the organization of the elements of any narrative. In that wise, it can be connected to linguistics. Besides, Barry further argues that narratology is a branch of structuralism that serves as its parental source though detached and liberated from it now (ibid.). This, Barry characterizes 
after the elements of stylistics. The position places narratology as a diaphragm between literature and linguistics (see Fowler 1981: 162). In Adedun's argument, one should seek to fashion out cooperation between linguistics and literature in order to bridge the existing gap (Adedun 2006: 532). Considering Adedun's approach, narratology is a subject that can address the lacuna envisaged. The structure of narrative intertwines with socially contextual devices. Thus, "This intergrating of a series of events into a sub-sequence is a feature of narratives in general. This includes not only fictional narrative but also narrative passages in biography, news reports and other kinds of text where past experience is construed" (Halliday and Matthiessen 2004: 365). It means that a story is told and at the same time being approached from both its syntactic sequence and contextual basis. This is the motivation for adopting transitivity system as a supporting tool to Labovian narrative contextualism.

Linguistics is about the analysis of the structure and sequence of language in use - discourse as a chain, a system and a social enterprise. The effort may be explored from Syntagmatic order or paradigmatic order. Either of the position tends to explain how a particular discourse is organized to reveal its patterning compositions and relationships of its constituents. In the same vein, the analysis of narrative can also be elucidated from either of the constituents of conceptual shapes (syntagms or paradigms). Although narrative may appear as minimal or complex in construct, the structure has been organized into taxonomy. Now, from a Syntagmatic approach, scholars (e.g. Greimas 1966; Labov 1972) have attempted to address the overall sequence and structure of narrative from its clausal domains as a recap of experience. Greimas (1966) describes the structural sequence by classifying it into six different ways of three pairs. The fundamental pairs Vestergaard and Schroder (1985) facilitate as subject-object; helper-opponent; and giver-receiver. The subject is the hero, as Vestergaard and Schroder particularly emphasize, who works hard to gain the attention of an important figure or to achieve greatness on his own. The opponent is an antagonist of the hero or an obstacle of the hero's desire whereas the helper provides the hero with assistance needed in order to achieve a certain aim. Consequently, the giver is more powerful than the hero and his object, the antagonist; the personnel hands over the pursuit of the hero to the individual. The hero or the ally becomes the receiver (Vestergaard and Schroder 1985: 27-28, see also Jaworski and Coupland 2006: 26). The model, in Greimas' view, represents actants (actors) that participate functionally in the replay of an event.

Labov's template seems to construct core concepts of narratology because it is applied effectively in social milieux (ibid.: 211). It is classified as a precious device in the analysis of recounting and refashioning anecdote. The classifications are: abstract, orientation, complicating action, evaluation, result or resolution and coda (Labov 2006: 219). Functionally, the concepts are referential elements that point to feelings of the actors and organize the story as happened outside the narrator's-receiver's current environment (Johnstone 
2002: 637). The abstract, according to Labov, is the synopsis of the narrative. It encapsulates the entire story which attracts the attention of its listener for prompting. Orientation is the recognition of functional clausal elements in terms of time, setting, persons, actions and contextual situation. This provides a detailed account of the occurrence. Labov further states that placement is the crux attraction in orientation (2006: 221). Complicating action constructs a form of suspension in the narrative that creates tenacity on the receiver. It is the tension created that result/resolution releases by explaining the finality of the hero's action or achievement. The coda contains the few clauses that offer a summary for the recit. The section indicates that the story is finished. The coda signals general observation as well as bridging the gap between the present (the end of the narrative) and the past (when the story began). Evaluation is the purpose of the historical replay. This seems contextual rather than structural for it bears semantic undertones. The question: "Why should a dramatis persona replay an event?" comes to the limelight (details in Johnstone 2002; Labov 2006).

In contrast to Labov's model of narratology, Edwards argues from a psychological point of view that the six instruments of shredding in Labov's narrative structural sequence are incomplete. They avert psychological, anthropological and enthnographic tenets (Edwards 2006: 234). Edwards proposes narrative contextualization from its communication interface and developing structural perspectives. He focuses narrative analysis from its gradual rhetorical construction - the mechanism or art of its design. Edwards' schema, one can argue, is not really a means of countering the Labov's model but rather a way of advancing it. He submits, to a considerable extent, to the explications of the Labovian template. However, Edwards argues that the Labov's model is not all inclusive for its limitation is found in its inability to account for rhetorical emergent and interactional elements of narrative (Edwards 2006: 227-234). These, he suggests, are very cardinal and considerable.

No one can contest the interdisciplinary nature of narrative. Functionally structurally, it, in one way or another, brings about cross-fertilization of ideas from scholars of different fields. It is a fact that makes the author to concur that irrespective of the queries regarding narrative, one has so much to learn and understand. That is, "from theories about systems and society developed by others as well as much to offer in showing others the value of close, systematic reading" (Johnstone 2002: 644). This view connects the phenomena that such conceptual framing devices are applied to. The narrative effect of advertising on consumers is a revelation of its importance in virtually all areas of human endeavor. Ad occupies such a position because it harnesses all the other genres to portray them as one unit entry (Cook 1992). This is a greater latitude of ad's operations. 


\subsection{Theoretical Schema}

\subsubsection{Transitivity System}

The study schematizes the selected narratives through the transitivity system for its ideational devices are strong in expressing the clause contents. That is, the contents that the speaker experiences in the real world (Butler 1985: 47). Ideational Metafunction is divided into experiential and logical relations. Halliday claims that the Ideational Metafunction exhibits the content of the goings-on in a text (Halliday 1994: 20). When we use language to interact, it is argued to be used to express either the external world or internal world (Eggins 2004: 213). Eggins observes further that we use words to talk about our experience - to construct the world - where "some entity does something" (ibid.: 215). Ravelli (2000) remarks that, the world around us, the external world could be - things, events qualities, etc. Our internal world could also be represented as -thoughts, beliefs, feelings, etc. Halliday (1994) further describes "experience" as consisting of goings-on - happening, doing, sensing, meaning, and being and become. He adds that "the clause is also a mode of reflection... and flow of events" (Halliday 1994: 106). Speakers articulate their thoughts, according to Halliday, to explicate meaning potential in confidence. These utterances are regarded as texts that are contextually produced with a particular content. It is explained that the speaker determines the content with particular meanings embedded thereof. In this regard, language seems to possess numerous resources that are employed to represent the entities in the world. Kress and van Leeuwen submit that the module of realizing and analyzing meanings from this perspective is called transitivity system (Kress and van Leeuwen 1996: 47). It is in that similar direction that Thompson glosses that the Process is brought about most times by nominal elements (Participants) involved in the event negotiating and exchanging interactions. There is also a possibility that a text may have circumstantial elements (Thompson 2004: 88-9). These might be argued to function in the appropriate parts of the clause sometimes which relate the content with further information.

The content is central to a clause function in terms of meaning potential and linguistic analysis. Halliday (1994) argues that each of the contents has its own distinct way of presenting both the external and internal world to language appreciators. In that perspective, explanation goes further that "Material, Mental and Relational are the main types of process in English transitivity system". On the borderlines of the three major processes are "Behavioral, Verbal and Existential" (Halliday and Matthiessen 2004: 171). There are six processes as Halliday and Matthiessen claim in the English transitivity system. They are Material, Mental, Relational, Behavioral, Verbal and Existential. The system network below further illustrates the transitivity system of an independent clause in English. 


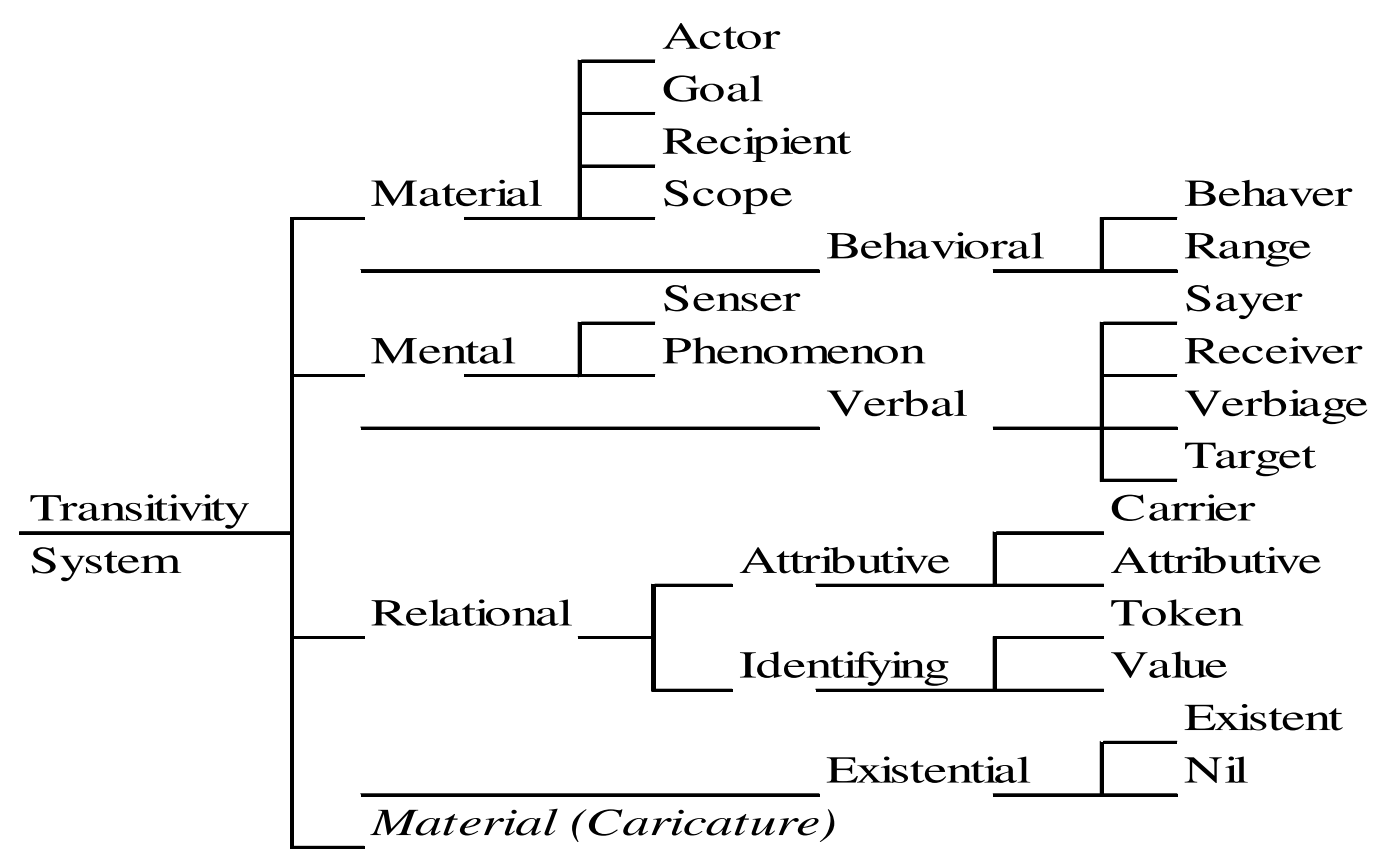

FIGURE 1: TRANSITIVITY SYSTEM NETWORK

One can further explain that the material processes, as shown in Figure 1, occupy the physical accomplishment of doing and happening (Thompson 2004: 90). Scholars including Ravelli (2000: 41) say that the mental processes construe the speaker's inner mind of imagination and consciousness whereas relational processes are of being and having (Halliday and Matthiessen 2004: 210). Eggins posits that the behavioral falls within the ambit of processes that relate to human psychological content (Eggins 2004: 233). And, of course, verbal processes function with verbal processes and reported speeches. The existential processes are suggested to express existence of an entity (Thompson 2004: 104). It is very significant to state that the existential processes are not so much common in communications. This is because they are processes that involve referencing the position or the state of an object. The functions engage a kind of pointing of fingers.

\subsection{Methodology}

The author collected four ads of First Bank of Nigeria (FBN), MTN, Orijin and Federal Inland Revenue Service (FIRS) from the Punch newspaper. The article employed transitivity system as a shredding instrument of text into various semiotic slots. The analyst employed tables and graphs in order to enhance quantitative analysis and as a means of characterizing the values of processes and circumstantials in the transitivity. A combination of Labovian framework and the outcome of transitivity is used as explanatory paradigms in the discussion. The study utilized dialectical forms of analyses of the ad frames of FBN, MTN, Orijin and FIRS in terms of both processes and circumstantial 
elements of the clauses in order to avert monotony. The ad frameworks embed within the discussion as a strategy of relating the plates with the explanations.

\subsubsection{Data Analysis}

\begin{tabular}{|l|l|}
\hline Tunji & thinks \\
\hline Behaver & Behavioral \\
\hline
\end{tabular}

\begin{tabular}{|l|l|l|l|l|l|}
\hline that & his salary & should be & enough & to pay & for his dreams \\
\hline & Actor & Mat- & Goal & rial & Cause:Purpose \\
\hline
\end{tabular}

\begin{tabular}{|c|c|c|c|c|c|}
\hline we & listened & we & gave & him & a joint mortgage \\
\hline Senser & Mental:Perception & Actor & Material & Recepien & Goal \\
\hline
\end{tabular}

\begin{tabular}{|l|l|l|l|}
\hline so that & he and his partner & can buy & their dream home; \\
\hline & Actor & Material & Goal \\
\hline
\end{tabular}

\begin{tabular}{|c|c|c|}
\hline a pers & 1 loan against sa & PLAS) \\
\hline Goal & & \\
\hline so he & won't struggle & till pay \\
\hline Actor & Material & Locati \\
\hline
\end{tabular}

\begin{tabular}{|l|l|}
\hline a naira credit card & for ease of purchase home and abroad \\
\hline Goal & Cause:Purpose \\
\hline
\end{tabular}

\begin{tabular}{|l|l|l|}
\hline FirstClub & to learn him reward ponits & $\begin{array}{l}\text { for all bills, card payments on POS and } \\
\text { deposit he makes on his accounts }\end{array}$ \\
\hline Goal & Manner:Degree & Cause:Purpose \\
\hline
\end{tabular}

\begin{tabular}{|l|l|l|l|l|}
\hline Because & we & put & you & first \\
\hline & Actor & Material & Goal & Manner: Degree \\
\hline
\end{tabular}

FIGURE 2: FBN NARRATIVE CLAUSE ANALYSIS 


\begin{tabular}{|l|l|}
\hline Children & today \\
\hline Participnt. & Location:Time
\end{tabular}$\quad$\begin{tabular}{|l|l|l|}
\hline and & Leaders & tomorow \\
\hline & Participnt. & Location:Time \\
\hline
\end{tabular}

\begin{tabular}{|l|l|l|l|l|}
\hline World children day & is & always & a great opportunity & to celebrate children today \\
\hline Carrier & Rel., Attr. & & Attributive & Manner:Degree \\
\hline
\end{tabular}

\begin{tabular}{|l|l|l|l|l|}
\hline The MTN Foundation & joins & Nigeria & from all works of life & to celebrate our children \\
\hline Actor & Material & Goal & Location:Place & Manner:Degree \\
\hline
\end{tabular}

\begin{tabular}{|l|l|l|}
\hline Who & are & tomorrow's leaders \\
\hline Carrier & Rel., Attr. & Attributive \\
\hline
\end{tabular}

\begin{tabular}{|l|l|l|l|}
\hline In support of effort & to ensure the fulfillment of their potential & we & have \\
\hline Manner:Quality & Manner:Degree & Actor & Mate- \\
\hline \multicolumn{3}{|l}{} \\
\hline made & considerable social investment & in areas \\
\hline rial & Goal & Location:Place \\
\end{tabular}

\begin{tabular}{|l|l|}
\hline not limited to & over 45,000 desks, benches and chairs \\
\hline Material & Manner:Degree \\
\hline
\end{tabular}

\begin{tabular}{|l|l|l|l|}
\hline that & have been distributed to & selected public schools & under the Learning \\
\hline & Material & Goal & Location:Place \\
\hline
\end{tabular}

\begin{tabular}{|l|l|}
\hline Facility Support Project (LFSP) & $\begin{array}{l}\text { along with thousands of exercise books, school bags, } \\
\text { raincoats and maths sets to students }\end{array}$ \\
\hline & Location:Place \\
\hline
\end{tabular}

\begin{tabular}{|l|l|}
\hline through the Learning Support Initiative & $\begin{array}{l}\text { over 4,500 scholarships connected to students in } \\
\text { tertiary institutions valued in excess of } 1 \text { billion naira }\end{array}$ \\
\hline Manner:Means & Manner:Degree \\
\hline
\end{tabular}

under the Science and Technology Scholarship Scheme

Location:Place

\begin{tabular}{|l|l|l|}
\hline 49 schools in 12 states across Nigeria & have benefitted & from the MTN SchoolConnect \\
\hline Senser & Mental:Emotive & Location: Place \\
\hline \multicolumn{3}{|l|}{} \\
\hline Project aimed at improving access to teaching & in digital literacy \\
\hline & Location:Place \\
\hline
\end{tabular}

\begin{tabular}{|l|l|l|l|}
\hline MTN Foundation & .. improving & the quality of life & in our communities \\
\hline Actor & Material & Goal & Location:Place \\
\hline
\end{tabular}

FIGURE 3: MTN NARRATIVE CLAUSE ANALYSIS 


\begin{tabular}{|l|l|l|}
\hline There 's & power & in our past \\
\hline Existent & & Location:Place \\
\hline
\end{tabular}

\begin{tabular}{|l|l|l|}
\hline The labour of our hero's past & $\mathrm{t}$ & in vain \\
\hline Carrier & Rel.:Attributive & Matter \\
\hline
\end{tabular}

\begin{tabular}{|l|l|l|l|l|}
\hline If & we & stay to & the orijinal intent of their fight & for independence of our motherland \\
\hline & Actor & Material & Goal & Cause:Purpose \\
\hline
\end{tabular}

\begin{tabular}{|l|l|l|l|}
\hline Their vision & was to unify & several rich and diverse cultures & to create a strong nation \\
\hline Actor & Material & Goal & Manner:Degree \\
\hline
\end{tabular}

\begin{tabular}{|c|c|c|c|}
\hline Where & peace, pride and justice & live & Happy Birthday Nigeria \\
\hline \begin{tabular}{|l|} 
Location:Place \\
\end{tabular} & Actor & Material & Minor Clause \\
\hline
\end{tabular}

\begin{tabular}{|c|c|c|c|}
\hline Her future & \multicolumn{2}{|l|}{ looks } & brighter \\
\hline Behaver & \multicolumn{2}{|c|}{ Behavioral } & Range \\
\hline When & we & pay & our tax \\
\hline Location:Time & Actor & Material & Goal \\
\hline
\end{tabular}

\begin{tabular}{|l|l|}
\hline Here 's & to our children \\
\hline Existent & Cause:Behalf \\
\hline
\end{tabular}

\begin{tabular}{|l|l|l|l|}
\hline Who & enjoy & a better tomorrow & through your prompt tax payment \\
\hline Senser & Mental:Emotive & Phenomenon & Manner:Means \\
\hline
\end{tabular}

\begin{tabular}{|l|}
\hline Happy Children's Day \\
\hline Minor Clause \\
\hline
\end{tabular}

FIGURE 5: FIRS NARRATIVE CLAUSE ANALYSIS

\subsubsection{Results}

Transitivity system of the narratives of the ad frameworks

Table 1 below indicates the processes as they recur in the ads of FBN, MTN, Orijin and FIRS. 


\begin{tabular}{|l|l|l|l|l|l|}
\hline \multirow{2}{*}{ Processes } & Product & \multicolumn{4}{|l|}{ Total } \\
\cline { 2 - 5 } & FBN & MTN & ORIJIN & FIRS & \\
\hline Material & 7 & 5 & 3 & 1 & 16 \\
\hline Mental & 1 & 1 & 0 & 1 & 3 \\
\hline Behavioural & 1 & 0 & 0 & 1 & 2 \\
\hline Relational & 0 & 2 & 1 & 0 & 3 \\
\hline Verbal & 0 & 0 & 0 & 0 & 0 \\
\hline Extistential & 0 & 0 & 1 & 1 & 2 \\
\hline Total & 9 & 8 & 5 & 4 & \\
\hline
\end{tabular}

TABLE 1: DiALECTICAL ANALYSIS OF THE PROCESSES OF FBN, MTN, ORIJIN AND FIRS ADS

Figures 6 and 7 are analyses that separate the total values demonstrated in Table 1.

\begin{tabular}{|l|l|}
\hline Product & $\begin{array}{l}\text { Total } \\
\text { Processes }\end{array}$ \\
\hline FBN & 9 \\
\cline { 1 - 1 } MTN & 8 \\
\cline { 1 - 1 } ORIJIN & 5 \\
\cline { 1 - 1 } FIRS & 4 \\
\hline
\end{tabular}

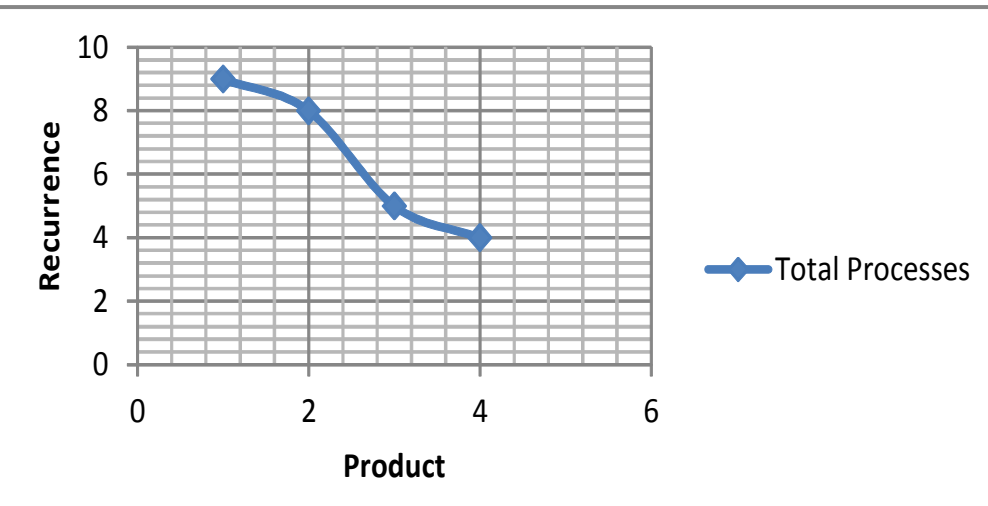

FIGURE 6: APPRECIATION OF PROCESSES IN EACH AD OF FBN, MTN, ORIJIN AND FIRS NARRATIVES

The material processes in Table 1 and Figure 6 record the highest value for FBN, MTN, Orijin and FIRS. Among others, FBN has 7 points which is followed by MTN of 5 points. Orijin and FIRS are the least of 3 and 1 points respectively. The ads also use relational, mental and behavioral processes once in a while as a means of persuading consumers. The values of the processes demonstrate the clauses as strategizing at the platform of happening and doing in order to influence the public. 


\begin{tabular}{|l|l|}
\hline Processes & Value \\
\hline Material & 16 \\
\hline Mental & 3 \\
\hline Behavioural & 2 \\
\hline Relational & 3 \\
\hline Verbal & 0 \\
\hline Extistential & 2 \\
\hline
\end{tabular}

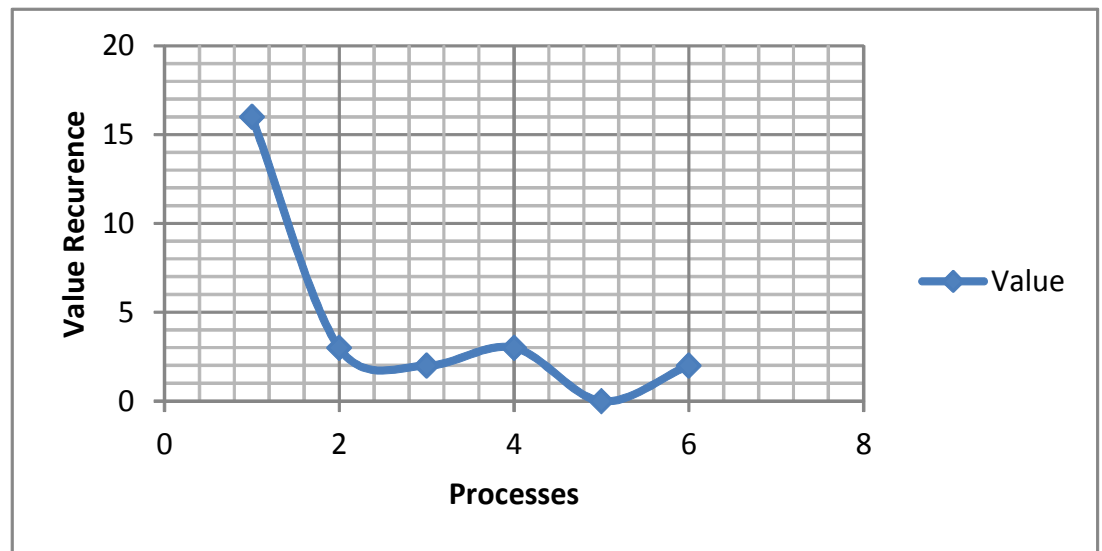

FIGURE 7: JUXTAPOSITION OF THE PROCESSES OF FBN, MTN, ORIJIN AND FIRS NARRATIVES

Apart from Figure 6 showing the processes of FBN and MTN as the highest, and Orijin and FIRS as the least, the total processes' values also demonstrate that material processes are famous in function. These account for about 16 points. The recurrence is an indicator of the direction that the messages of FBN, MTN, Orijin and FIRS focus. Figure 7 signals mental, behavioral, relational and existential processes as playing supportive roles. With the appearance of the graph, one can suggest that FBN, MTN, Orijin and FIRS utilize material processes as the contents to incite the recipients to patronize the advertised goods and services.

\section{Circumstantial devices of the narratives of the ad frameworks}

Table 2 illustrates the values of circumstantial elements as they function in the ads of FBN, MTN, Orijin and FIRS

\begin{tabular}{|l|l|l|l|l|l|l|l|l|l|l|}
\hline \multirow{2}{*}{ Product } & Circumstantial & Total \\
\cline { 2 - 11 } & Role & Angle & Location & Extent & Contingency & Accompaniment & Cause & Matter & Manner & \\
\hline FBN & 0 & 0 & 1 & 0 & 0 & 0 & 3 & 0 & 2 & 6 \\
\hline MTN & 0 & 0 & 9 & 0 & 0 & 0 & 0 & 0 & 7 & 16 \\
\hline ORIJIN & 0 & 0 & 2 & 0 & 0 & 0 & 1 & 1 & 1 & 5 \\
\hline FIRS & 0 & 0 & 1 & 0 & 0 & 0 & 1 & 0 & 1 & 3 \\
\hline Total & 0 & 0 & 13 & 0 & 0 & 0 & 5 & 1 & 11 & \\
\hline
\end{tabular}

TABLE 2: DiALECTICAL ANALYSIS OF THE CIRCUMSTANCES OF FBN, MTN, ORIJIN AND FIRS ADS

Figures 8 and 9 identify in distinct forms the combined values of the entities in Table 2. 


\begin{tabular}{|l|l|}
\hline Product & Circum. \\
\hline FBN & 6 \\
\hline MTN & 16 \\
\hline ORIJIN & 5 \\
\hline FIRS & 3 \\
\hline
\end{tabular}

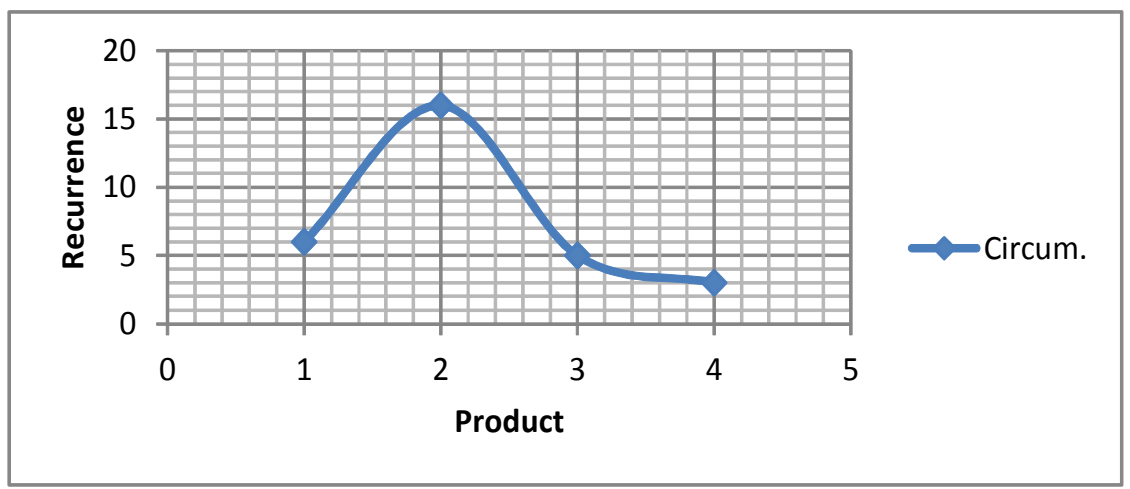

FIGURE 8: APPRECIATION OF CIRCUMSTANCES IN EACH AD OF FBN, MTN, ORIJIN AND FIRS NARRATIVES

The analysis of the circumstantial elements in Table 2 and Figure 8 reveal MTN as deploying more of the elements in the clauses than FBN, Orijin and FIRS. This is because about 16 circumstantial devices operate in the clauses of MTN alone. Among them location in terms of, most especially, place records the highest value. In a similar vein, 7 circumstances of manner are recorded. Observation shows the narrative of MTN as the longest among the others that is a logical reason for having more circumstantial system than the rest operators of the ads. These support the contents of the message for a purpose of value augmentation. There are 6 and 5 circumstances in both the FBN and Orijin ads respectively, which domains of functions are cause, manner and location. FIRS uses less of the circumstantial, however, this may be as a result of the size of the clauses of the narrative. The argument on the pattern of the recurrence is that the advertisers' focus of interest is location exemplified in terms of place (domain) and time (urgency) of the messages.

\begin{tabular}{|l|l|}
\hline Circumstantial & Value \\
\hline Role & 0 \\
\hline Angle & 0 \\
\hline Location & 13 \\
\hline Extent & 0 \\
\hline Contingency & 0 \\
\hline Accompaniment & 0 \\
\hline Cause & 5 \\
\hline Matter & 1 \\
\hline Manner & 11 \\
\hline
\end{tabular}

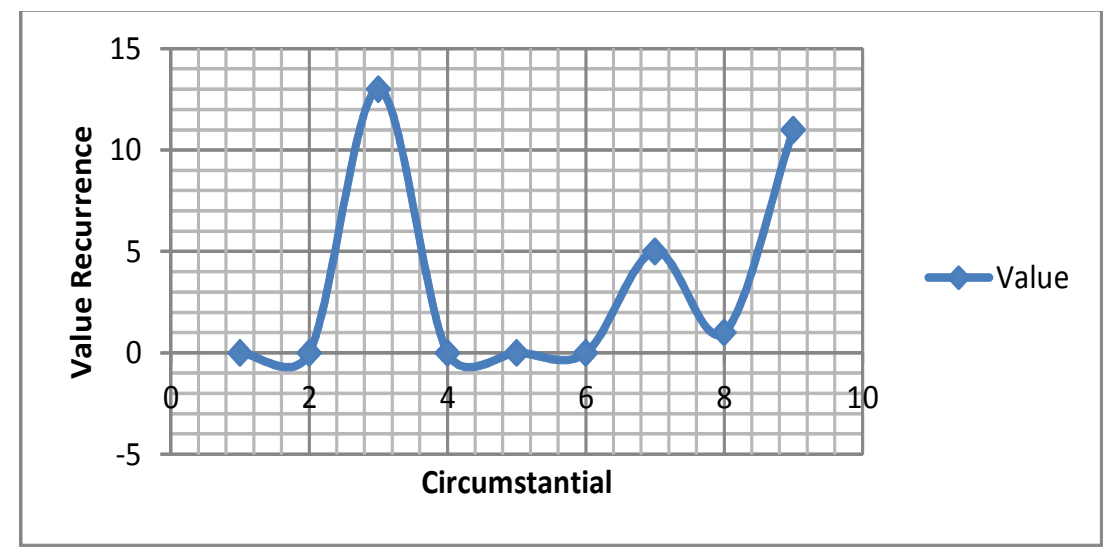

FIGURE 9: JUXTAPOSITION OF THE CIRCUMSTANCES OF FBN, MTN, ORIJIN AND FIRS NARRATIVES

The cumulative in Figure 9 shows location as the prominent utilitarian device. The circumstance of manner trails that. Cause supports those ones with 
about 5 points. By implication, the advertisers of FBN, MTN, Orijin and FIRS associate with both the circumstances of location and manner as the enhancement of the messages in order to encourage the target audience adhere to the pieces of information.

\subsubsection{Discussion}

Figures 6, 7, 8 and 9 demonstrate statistical representations of transitivity system of FBN, MTN, Orijin and FIRS narratives. The illustrations are based on the semiotic slots allotted to them as observed in Figures 2, 3, 4 and 5. The table and graph in Figure 6 indicate that most of the processes in the narratives are material processes in MTN where relational processes occur two times. Mental, Behavioral and Existential processes function at a minimum of one time. However, verbal process does not operate at all. It demonstrates that the narratives concretize properly in of being and having as earlier mentioned. They function partially in other processes. In Figure 7, the operational compasses of the circumstantials signal Location and Manner. Both of them occur in the MTN narrative. The circumstance, Cause functions more in FBN about three times and one time each in others. It means that the dominant role of Circumstantial is noticed more in Location and Cause, while others such as Role, Contingency, etc. perform no function in the narratives.

There are eleven clauses in the analysis of the FBN narrative. Using the Labovian framework, clauses one and two represent the abstract, clause three depicts orientation and complicating action is observed in clause two. The result is in the clauses four, five, six, seven, eight nine and ten. The coda is in clause eleven. Tunji thinks that his salary should be enough to pay for his dreams is the statement that summarizes the message of the narrative. The aim is to introduce the public to the mission of the message. It mentions Tunji's desire about his monthly salary. Salary is a lexeme adopted to sensitize the public about its importance in the life of every worker. The ad orientates the audience by showing the concern of FBN to Tunji's worries and pathetic financial situation that he is unable to manage. It is in that sense that we listened is injected to the narrative. This shows that the FBN team has listening ears to people's financial challenges. 


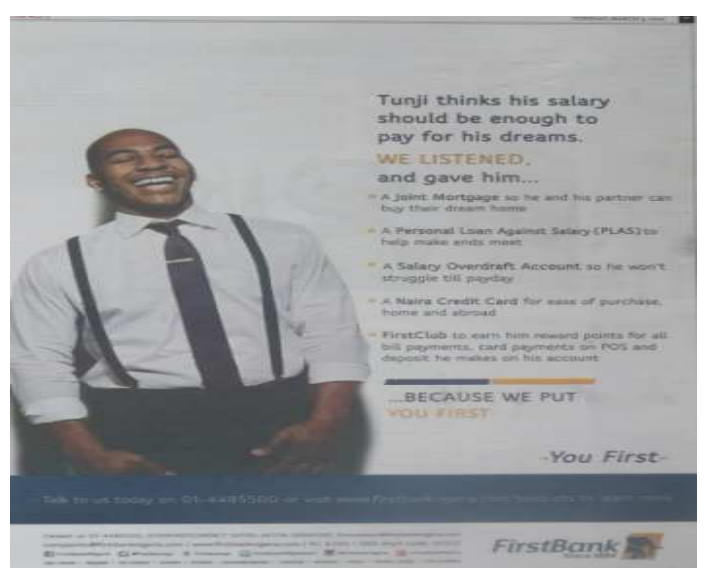

TX-1 (FBN)

His salary should be enough to pay for his dreams serves as a complicating action. A company expects that a worker's salary should be enough to take care of certain needs. In Tunji's situation, the reverse is the case. In the real sense of it, the salaries of so many workers have failed to meet their needs. Hence, they go in search of alternative means. The individuals source for additional means of income. The complication comes in when "their take home cannot actually take them home" - being a common metaphor among Nigerian civil servants. The circumstance tends to proliferate the financial thought of the target audience. This singular clause will stimulate the audience to listen to what FBN has to say. The teeming concern is resolved through the solutions proffer to people's financial problems. Tunji as the hero received five things as helps from FBN. He got a join mortgage, a personal loan, a salary overdraft, a naira credit card and FirstClub product to ease his financial challenge. The concentration of narrative is in its resolution. This demonstrates FBN's nature of financial generosity. All the packages are presented as "helps" and "gifts". However, they are burdens a worker will bear and pay back later. If care is not taken, anyone who enjoys or intends to enjoy all these benefits might not have financial independent all his life. The person may be on servitude to FBN because there are charges on many financial benefits gained from financial institutions.

The persona projects the reason for histoire as an assistance provided for Tunji's inability to pay for his dreams. The dreams are evaluated as buying the dream home, home and abroad. He needs helps to avoid struggling before the payday and to earn reward point for all his bills based on the deposit he makes on his account. Tunji is an actant in the narrative but the resultant effect on the people that submit to the ad's instruction is that individuals will equally enjoy the benefits that Tunji enjoys. Outside the clauses of the narrative, it can be mentioned that FBN is enticing consumers to patronize their product. It is in the patronization that FBN can grow its business as well as competing favorably conveniently with other financial institutions. The coda, Because we put you first, comes as the conclusion of the recit. FBN claims with the utilization of the 
structural organ that customers are kings in the business. Thus, it concludes the efforts of the financial institution to retain consumers' confidence and to win more.

Seven processes operate in the FBN narrative clauses and they are thinks, should be...to pay, listened, gave, can buy, won't struggle and put. Thinks is a behavioral process that refers to the way Tunji's ponders over his financial challenge. He communicates to himself in a manner to find solutions to his problem. Should be...to pay is a material process that expresses the ability to afford certain social amenities in life by giving money in exchange for those necessities of life. These facilities have the capacity to make someone comfortable and joyful. A mental process, listened, establishes the perception of FBN regarding the challenges of Tunji. The attention paid to his thoughtful complaints inspires FBN to proffer solutions to his dreams. FBN is Tunji's financial survival and wants to be to others as well. One can easily argue that the application of Tunji's situation and gains in an umbrella setting is phenomenally theoretical. Gave, can buy, won't struggle and put are material processes which indicate doing and having. Gave indicates the transfer of the possession of FBN to Tunji in order to carry out certain financial transactions in the social system. It is good to point out that the material process, gave, is punctuated from clauses 6, 7, 9 and 10. The shift of financial possession makes the Goal, Tunji, to be financially buoyant. That is the reason for using can buy as a pointer to how Tunji has been up-graded and has less contention with money for he won't struggle to achieve his dream any longer. He does not rely solely on his salary but on the provisions that FBN has made for him. FBN places the client as the first choice in several undertakings that is why put as a process is deployed. It further indicates the significant role that the customer plays in banking transactions. Certain background details such as for his dreams, till payday, for ease of purchase home and abroad, etc. are deployed to enhance the narrative. Meanwhile, the picture of a happy young man, who the author can suspect to be Tunji, supports the message of the clauses. This reveals how the people will be and their needs be met provided they obediently accept the message. 


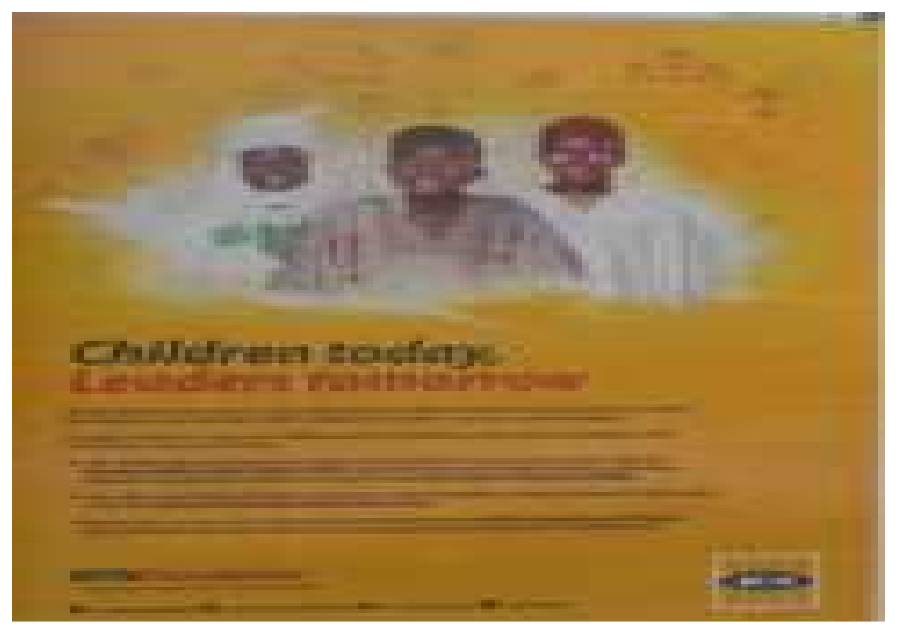

TX-2 (MTN)

The analysis in Figure 3 has ten clauses that protract the three children pictures in the ad. The pictures are mimics of late sages of the Nigerian Independence. They are Obafemi Awolowo, Nnamdi Azikiwe and Abubakar Tafawa Balewa. The significance of the images is the interchangeability of the old for the new, the ancient for the modern and the past for the present. This can serve as an inspiration for the growing children in order to look forward to being leaders and taking up leadership responsibilities. Such is replicated through the dresses, caps and pairs of glasses that the children wear. A sort of relay is observed in the entire ad (Vestergaard and Schroder 1985). The pictorial elements and texts provide useful meanings in a reciprocal manner. It is difficult to undermine the meaning contributions of either the image or the text. This is because Awolowo, Azikiwe and Balewa are icons in the historical evolvement of Nigeria. However, the popularity of the images is further supported with linguistic devices to provide adequate meanings that show the gradient of the narrative.

In Figure 3, clauses one and two depict the abstract, while clauses three, four and five represent the orientation of the narrative to the audience. And at the same time, clause five projects the complicating action. The persona uses clauses six, seven, eight and nine to ease the suspension in clause five. The culmination of the resolution is concluded as the coda is represented in clause ten. The narrative begins with two elliptical clauses, children today and leaders tomorrow, which provide the summary of the message. The images which represent the past are linked to both the present and the future in clauses one and two. Awolowo, Azikiwe and Balewa were children in the past, who later turned leaders in the past as well. It is in that wise that the children of the present will eventually become leaders in the nearest future. The two clauses as deployed construct a tune for the narrative by connecting today's children to the past and the future at the same time. There is a lesson for children in flashing back and to understand a commitment to make in order to become future leaders. 
The noun phrase (NP) in clause three, World Children Day, is a reference to a special day that children are honored worldwide. This is where the orientation starts from. The clauses read thus: World Children Day is always a great opportunity to celebrate children today; The MTN Foundation joins Nigeria from all works of life to celebrate our children. The elaboration of the message shows children as celebrants and Nigeria (people) as a part of the globe also felicitates with them. In this quest, MTN Foundation seizes it as a great opportunity and avenue to connect itself with the children fete day. The foundation portrays the orientation as very significant so that the public can notice its participation in the fiesta. The engagement may influence the public to patronize MTN products which in a way is the primary assignment of the narrative. This remark can be supported with the prepositional phrase, from all works of life. MTN is a telecommunications firm (telecoms) that provides services for Nigerians irrespective of tribes, religions, age or profession. It might be in that sense that the idea of from all works of life is developed. MTN joins Nigerians to admire children through connecting them everywhere they are and go.

The indicative text, Who are tomorrow's leaders, is use to propagate complication. MTN expects the audience to envisage the position of leadership as a difficult task to attain and sustain. There are challenges in becoming a leader as well as playing a leadership role. For any child to become a future leader, such an individual must dedicate self to studying very hard and to a particular level which the three referenced icons did. It is during the study activities that a child will understand, learn and possess leadership qualities such as faithfulness to the people and country, commitment to his work and service to humanity, love and care for the less privileged, etc. All these and others are devices that give a child the needed integrity. It is that unbroken totality of humanness that will build trust on the people and the people's on the individual. The turbulence of suspense created is purged through the enumerated actions that MTN has taken to assist the children to realize the potential of leadership in the proceeding statements.

The theatrical persona begins the resolution of the suspense created thus: In support of effort to ensure the fulfillment of their potential we have made considerable social investment in areas not limited to... The remark does not only proffer solution to the challenges of the leadership role to be attained; it, as well as, describes MTN as a responsible company that cares about the future of Nigerians. The social investments made are numerous, according to MTN. Among these are over 45,000 pieces of furniture, which have been sent to public schools. Exercise books, school bags and other materials are not left out of the effort. It accounts further that MTN has awarded 4,500 scholarships to students in tertiary institutions. Those, according to the actant, are of one billion naira value. The final record points out that 49 schools in 12 states across Nigeria benefit from the MTN SchoolConnect. However, the resources benefitted are neither highlighted nor explained in the print. Significantly, the resolution projects the 
donation that MTN has made to school in ensuring that today's children are trained to becoming the leaders of tomorrow. No one knows whether the reports on education are sacrosanct or otherwise. There are no fact-finders for the confirmation of the claims. One thing is sure: the resolution promotes and represents MTN as an entity that is interested in developing the leadership in children. If the account is righteous enough, seeing or reading about MTN's efforts towards children intellectual growth and development can boost sales of goods and services. This might have propelled the narrator to conclude that MTN Foundation is improving the quality of life in our communities.

In most advertising situations, the objective is to draw consumers' attentions (Myers 1986; Dyer 2005). The MTN ad is not operating without that web of persuasion. One can appraise that MTN identifies with children in order to get through to their parents. The fraternization can enhance patronization of the advertised services. It is expected that when the children of today become leaders in future MTN should have a place in their hearts and homes, most especially in the area of communicating one with another.

Apart from the fragmented clauses, there are eight processes in the narrative for the products. They are is, join, are have made, not limited to, have been distributed, have benefited and improving. The processes, is and are in clauses three and five relate Carrier to Attributive. World Children Day is related to a great opportunity while who (i.e. children) relates to tomorrow's leaders by a way of quality. The participants are attributive in nature because of their status of irreversibility. The mental process, joins, reveals the mission of MTN to be part of the Nigerian family in order to build formidable connections. The affinity can elicit the celebration of children. It is in that wise that have made is employed to show the extent of effort that MTN makes to supply them school materials. The effort is done without any restriction. The scope, according to MTN, covers a range of items which is the reason for introducing the material process not limited to in clause seven. Not limited to provides an opportunity for the enumeration of the list of items provided for schools on behalf of children. The attempt is to explain to the public their contributions to build a worthwhile future for children through social amenities. Have benefitted is mentally emotive which demonstrates a kind of feeling. The feeling is a sort of enjoyment as MTN asserts that 49 schools in 12 states gain from it. The process, improving, is deployed to indicate the manner that MTN Foundation ameliorates how the establishment makes deliberate efforts to ensure substantial improvement in people's standard of living.

Some of the clauses contain further information about the goings-on. Some of these are located, for instance, in clauses 3,4, and 6. The circumstantials to celebrate children today, and to ensure fulfillment of their potential, appear as processes whereas they are not. To celebrate and to ensure are circumstantials of Manner that indicate Degree. They are deployed in the narrative to enhance the message. Other circumstances in the same level of operation are over 45,000 
desks, benches and chairs; and over 4,500 scholarships awarded to students in tertiary institutions... They are also employed for augmentation purposes. Besides, there are circumstances of Location that indicate places. Some of them are from all works of life, under the learning Facility Support Project (LFSP), and in our communities. These are also deployed to enrich the narrative. Another type of circumstance is Manner that functions as Means. This is deployed as through the Learning Support Initiative for the same purpose of augmentation. In all, the enhancement operations of the circumstantials show Manner in Degree, Quality and Means; Location in Time and Place.

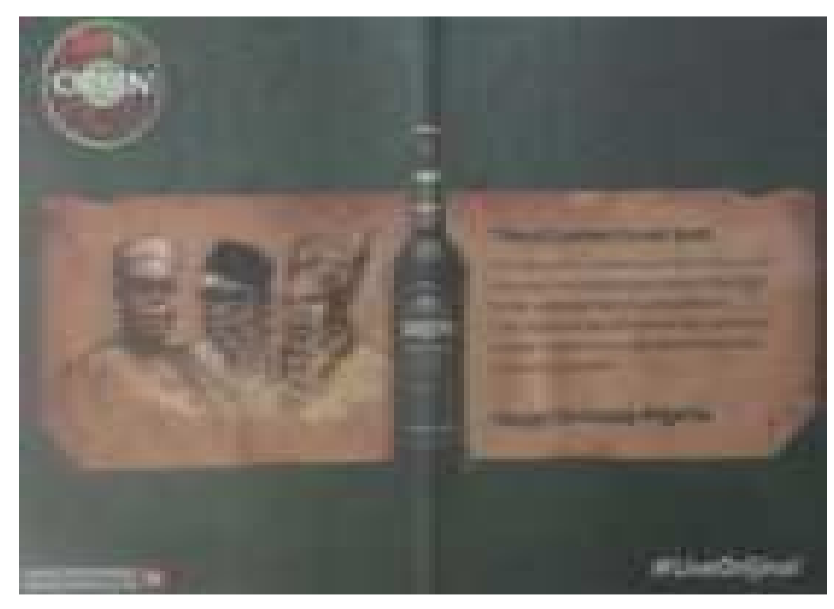

TX-3 (ORIJIN)

The narrative of Orijin contains six clauses. Five out of which are independent while the sixth one is a minor clause. Though it is minor, it is still considered as part of the narrative. There's power in our past is the abstract that provides the synopsis of the message. In this regard, our past points to the way that previous Nigerian heroes fought for independence of the country. This compels the Orijin ad to reflect our past through the pictures of Awolowo, Azikiwe and Balewa. They were icons, as earlier stated, that confronted the colonial masters and colonialism toothlessly with several strategies to "purchase" freedom for the Nigerian nation. Unlike the MTN ad where the mimic of these heroes are propagated through children; Orijin projects to the audience the iconic images as representations of our past. Significantly, our past reflects a joint effort that the trilogical personae made as a fighting team against colonialism. That effort did not only bring liberty to Nigerians but brought about the unification of all tribes. The reference of the past expects all Nigerians to fight a course of unity as our heroes of the past.

The ad further enthuses Nigerians that The labour of our hero's past shall not be in vain. The orientation is to encourage Nigerians about the phenomenal activity of the past leaders. The focus is about the past leaders as a captivating strategy to sensitize the people for adequate attraction. It could be noted that Awolowo, Azikiwe and Balewa are un-obliterated referential points in the 
history of Nigeria. Seeing their images and mentioning their names in text are plausible. Such an effort is very strategic in adding a semantic flavor to the narrative for both its cultural, social and ethic underpinnings. The public is enjoined to flash back to the past and act like the fathers of independence. It is in such behavior that The labour of our hero's past shall not be in vain becomes fruitfully operational. Fortunate enough, the clause is adopted from the Nigerian National Anthem. The complication is built through If we stay true to the orijinal intent of their fight for independence with a vision to unify... rich and diverse cultures... These clauses have the potency to arouse people's interest in order to take up challenges that face the nation. The clauses awaken the morale of citizens to behave rationally logically. The clauses excite people to emotional sensitization to building Nigeria social systems. Apart from the independence which is of the past, the concept of unity is referred. Unity projects the core value needed to survive as a people. Nigerians must be united as a people with one strong vision, one indivisible mind and undivided spirit without recourse to ethnicity or tribalism. It is such attitude that can bring growth and development to the country. So, the complicating action is a stimulant that reminds people of what their responsibilities are.

The dramatis persona unveils the suspense created through Where peace, pride and justice live to subside it. Three things are the resultant effects of flashing back to the efforts of the past heroes and act in similar dimensions. They are listed as peace, pride and justice. The trio can be seen as a sort of insinuation to the present generation. It seems that peace, pride and justice were operating in the past leaders but they are lagging behind in the systems now. The only path of restoration, according to Orijin, is the wield the power of the past, the desire of the past, the focus of the past, the unity of the past as well as the behavioral attitudes of Awolowo, Azikiwe and Balewa to the present. The coda is exemplified through a congratulatory message, Happy Birthday Nigeria. It needs not mention that the ad is an independent day element for the minor clause indicates it to be so. The persona refers the past in order to bring the present as a rousing linguistic device. The individual also demonstrates the strength of the past leaders that are purposefully meant to fight and gain independence in order to create a strong nation that everyone will enjoy and be proud of. It is in that sense that one can evaluate the narrative as a moral agent that points at the loyalty expected from all Nigerians in order to sustain the vision of Awolowo, Azikiwe and Balewa.

In the systemic perspective, There's is an existential process that refers the public to the power available in flashing back to the efforts of the past leaders. Shall not be relates The labour of the heroes of the past to the behavior that citizens are expected to put on today to commemorate their achievements. Stay to indicates the continuity expected from the current generation of Nigerians to sustain the fight of the heroes. The attitude is to consolidate the actions of the fathers of Nigeria. This is the reason that the process, was to unify in clause four 
expresses unity that can merge us as an indivisible entity. The inanimate actors, peace, pride and justice, are a style of life that will accomplish the recipients if the narrative actually has a place in their hearts. It is in that regard that live as a material process is deployed. The background information expresses Location, Matter, Cause and Manner. In our past and where are Location in terms of Place and Time. In vain is Matter which indicates projection that shows what the clause it about. The enhancement of Manner reveals the purpose of their vision of unification in order to create a strong nation in terms of Degree.

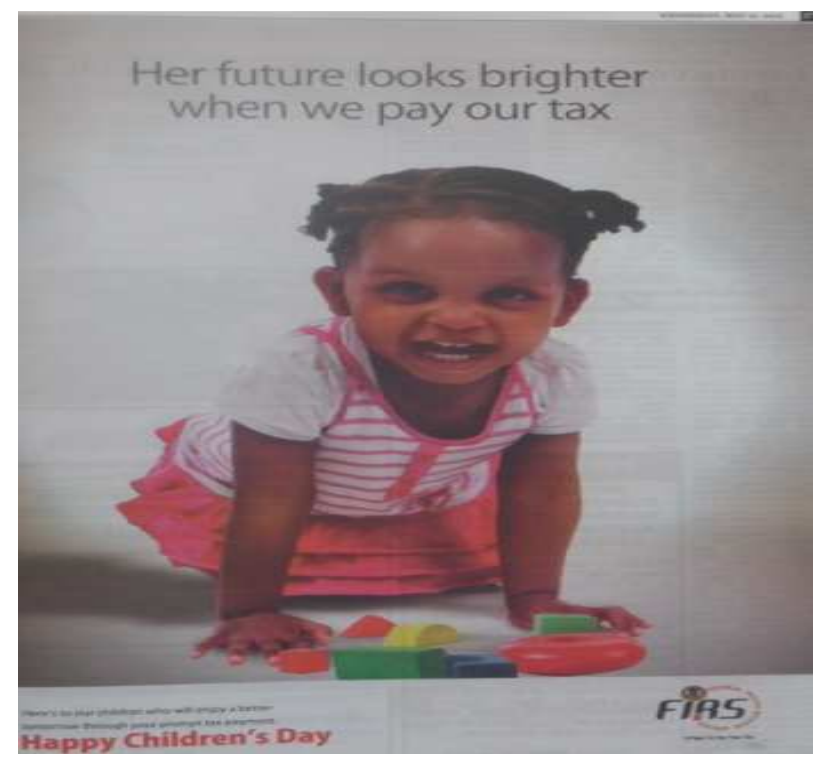

TX-4 (FIRS)

The narrative of FIRS has five clauses. The clauses are relays to the image of a crawling baby. The first clause, Her future looks brighter, is the abstract that summarizes the entire narrative. The application of the lexeme, future, seems to have a link with the past. In a sense, the past of the children in society might have been pathetic and hopeless. Even in the present dispensation, it, perhaps, means that the government does not cater for them. That then becomes a challenge to the authorities on how to assist children. That could be the raison d'être for deploying a complicating clause that when we pay our tax something will be done. To the public, paying tax of any amount and form is usually problematic. Hardly could one see someone to be paying the tax due voluntarily. Paying of tax is somewhat expensive because it is taken from one's resources. People might prefer to evade tax in order to use the money for family upkeep or something else rather than pay it. These are compelling reason for governments at all levels to regulate the payment of tax with sound legislations. For the dramatis persona to connect the brighter future of children to the payment of tax creates a concern for the audience. In respect of that further orientation is provided so that the purpose of paying tax can be understood and justified. Here's to our children is deployed to clear the coast of doubt. Using 
children for propagating an ad is a smart decision because virtually everyone loves children and cares for them. That characterizes the aim of the institution for linking children, who are helpless and dependent, to the payment of tax in a regular basis. The information is that the tax of the people will be used to cater for children. If people desire that the government should take care of children then parents must pay their tax. This is a trap set for taxpayers so that there will be no complaint in the future about the negligence of government on children's welfare.

The persona aborts the suspense created by providing an additional benefit of the payment of tax by stating that Who enjoy a better tomorrow through your prompt tax payment. The payment of tax, according to FIRS, is timely. It is not at will or a convenient time. Tax should be paid as regulated by the appropriate authority. It is in the payment that the future of the children will be secure. The security of children's prospect is the resolution that brings peace of mind to the public who have been advised to promptly pay their tax. The narrative imports the past to the present and connects the future of the children. The strategy is welcoming because children have been projected as the leaders of tomorrow. It means that the decisions about the parents of today and the country which they live in will be taken by today's children. That understanding about children and the future can ignite parents to the payment of taxes at all cost. Parents have been adequately induced that the benefits of paying tax is not for them but for their children. The persona concludes thus: Happy Children's Day. The Children's Day is a global phenomenon. FIRS's participatory role seems not to be concerned about the day of celebration per se but about the payment of tax. It is a statutory responsibility that will provide children a better future.

There are four processes in the narrative. They are looks, pay, Here's and enjoy. Looks characterizes the behaviors of the Behaver to indicate a certain attitude. Pay is a material process which informs the audience about the money they need to give necessarily to the state for the maintenance of children. Here's is a reference to the purpose of tax payment, which is for the children. Finally, the persona uses enjoy as a mental process to energize the emotional status of the audience. The process, enjoy, refers to the pleasure that the children, who are leaders of tomorrow, will receive from the payment of tax. In conjunction with the processes, circumstantial elements, when, to our children and through your prompt tax payment are deployed as Location to indicate Time, Cause to express Behalf and Manner that reveals Means. All the circumstantial devices enhance the message of the FIRS narrative.

\section{CONCLUSION}

Narratives in advertising follow after the Labovian structural account. They are expressed in form of abstract, orientation, complication, resolution and coda. 
Among these, the focus has been on the resolution to demonstrate the modus operand of how to ease the suspense created through complication. For instance, seven clauses out of eleven in FBN and four clauses out of ten in MTN portray resolution. The development shows the benefits that the target audience will derive from the goods and services advertised. They also indicate the care and goodness of the companies towards the public. Besides, the material processes such as gave, can buy, joins, stay and pay which spur people to action are deployed as instruments of sensitization. There are also processes of mental and behavioral, e.g. enjoy, benefit and look, that induce the audience to act in particular ways other than at will. Two major circumstantials - Location and Manner - function in the narrative as a pointer to detail the message. They reveal place, time, means and degree. In all, it shows that narrative is a relevant tool in advertising for it has the capacity to influence the audience to purchase goods and services. The study suggests that narrative can serve as a strategy of persuasion in advertising. It reminds the citizens of the past in both social and historical spheres. Besides, narrative tends to create lessons for the recipients by shaping and channelling a particular direction of thoughts for the target audience. Deploying advertising frameworks in forms of storylines can be fascinating and influential for many people seem to love listening and reading stories.

\section{BIBLIOGRAPHY}

AdEdun, E. A. (2006), Literary Elements as Communicative Strategies in Advertising. Literature, Language and National Consciousness: A Festschrift of Theo Vincent, 524533.

BARRY, P. (2009), Beginning theory: An introduction to literary and cultural theory ( $3^{\text {rd }}$ ed). New York and Manchester: Manchester University Press.

BUTLER, C.S. (1985), Systemic linguistics theory and applications, London: Batsford Academic and Educational

CARTER, R. \& NASH, W. (2013), Seeing through language, Lexington, KY: Blackwell.

CHOMSKY, N. (1972), Language and mind, Harcourt, Brace: Jovanovich.

COATES, J. (1996), Women talk: Conversation between women friends, Oxford: Blackwell.

COOK, G. (1992), The discourse of advertising. London: Routledge and Kegan Paul.

DYER, G. (2005), Advertising as communication. London: Routledge.

EDWARDS, D. (2006), "Narrative analysis" in Jaworski, A. \& Coupland, N. (2006). The discourse reader, New York: Routledge, p.227-238.

EGGINS, S. (2004), Introduction to Systemic Functional Linguistics, London: Continuum.

FLEISCHMAN, (2002), "Language and medicine" in Schiffrin, D, Tannen, D and Hamilton, H. (2002) The handbook of discourse, p. 470-502.

FOWLER, R. (1981), Literature as discourse: The practice of linguistic criticism, Bloomington: Indiana University press.

GreIMAS, A. (1966), Sémantique structural, Paris: Larousse. 
HALLIDAY, M.A.K. (1994), An Introduction to functional grammar, Great Britain: Hodder Arnold.

HALLIDAY, M.A.K \& MATTHIESSEN M. I. M. (2004), An introduction to functional grammar, Great Britain: Arnold.

JAWORSKI, A. \& COUPLAND, N. (eds.). (2006), The discourse reader. New York: Routledge.

JOHNSTONE, B. (2002), "Discourse analysis and narrative" in Schiffrin, D, Tannen, D and Hamilton, H. (2002). The handbook of discourse. p. 635-649.

KRESS, G. \& VAN LEUWEEN, T. (1996), The grammar of visual design, London and New York: Routledge.

LABOV, W. (1972), Language in the inner city, Philadephia: University of Pennsylvania Press.

LABOV, W. (2006), "The transformation of experience in narrative" in Jaworski, A. \& Coupland, N. (2006), The discourse reader, New York: Routledge, p. 214-226.

LINDE, C. (1993), Life stories: Equation of coherence, Oxford: Oxford University Press.

MYERS, K. (1986), Under stains: The sense and seduction of advertising, Surrey: The Gresham Press.

OCHS, E. and TAYLOR, C. (1992), "Family narrative as political activity", Discourse and society 3, p. 301-340.

PATRICK, P. and PAYNE-JACKSON, A. (1996), "Functions of Rasta talk in a Jamaican Creole healing: 'A bigfoot de gi' mi'", Journal of linguistic anthropology 6, 47-84.

PORTER, M. (1988), “Mothers and Daughters: Linking women's life histories in Grand Bank, New Foundland, Canada", Women's studies international forum 11, 545-558.

RAVELLI, L. (2000), "Getting started with functional analysis of texts" in Unsworth, L. and Christie F. (2000), Researching language in schools and communities, London: Cassell, 1- 26.

SILBERSTEIN, S. (1988), "Ideology as process: Gender ideology in courtship narratives" in A. D. Todd and S. Fisher (eds), Gender and discourse: The power of talk, Norwood, NJ: Ablex, p. 125-49.

THOMPSON, G. (2004), Introducing functional grammar, Great Britain: Hodder Arnold.

VESTERGAARD, T. \& SCHRODER, K. (1985), The language of advertising, Oxford and New York:Basil Blackwell.

\section{APPENDICES}

\section{FBN}

1. Tunji thinks

2. that his salary should be enough to pay for his dreams

3. we listened

4. and we gave him... a joint mortgage

5. so that he and his partner can buy their dream home;

6. a personal loan against salary (PLAS);

7. a salary overdraft account

8. so he won't struggle till payday; 
9. a naira credit card for ease of purchase, home and abroad;

10. we gave him FirstClub to earn him reward points for all his bills, card payments on POS and deposit he makes on his account

11. Because we put you first

\section{MTN:}

1. They are Children today,

2. and Leaders tomorrow

3. World children day is always a great opportunity to celebrate children today

4. The MTN Foundation joins Nigeria from all works of life to celebrate our children

5. Who are tomorrow's leaders

6. In support of efforts to ensure the fulfillment of their potential, we have made considerable social investment in areas

7. That are not limited to: over 45,000 desks, benches and chairs

8. that have been distributed to selected public schools under the Learning Facility Support Project (LFSP), along with thousands of exercise books, school bags, raincoats and maths sets to student through the Learning Support Initiative; Over 4,500 schoolchips connected to students in tertiary institutions valued in excess of 1 billion naira under the Science and Technology Scholarship Scheme;

9. 49 schools in 12 states across Nigeria have benefitted from the MTN SchoolConnect Project aimed at improving access to teaching in digital literacy

10. MTN Foundation... improving the quality of life in our communities

\section{ORIJIN:}

1. There's power in our past

2. The labour of our hero's past shall not be in vain

3. If we stay true to the original intent of their fight for independence of our motherland.

4. Their vision was to unify several rich and diverse cultures to create a strong nation

5. Where peace, pride and justice live.

6. Happy Birthday Nigeria

\section{FIRS:}

1. Her future looks brighter

2. When we pay our tax

3. Here's to our children

4. Who enjoy a better tomorrow through your prompt tax payment

5. Happy children's Day 